\title{
An Analysis of New VAT Law in Bangladesh: Changes \& Challenges
}

\author{
Taslima Khanam*(D, Anju Man Ara Begum, Sufia Khanam, Fatema-tuj-zuhra \\ International Islamic University Chittagong (IIUC), Kumira, Chittagong, Bangladesh \\ Email: ^Law4humanity@gmail.com,adv.anjum@gmail.com,adv.sufialawcu@gmail.com,fatematujzuhra@yahoo.com
}

How to cite this paper: Khanam, T., Begum, A. M. A., Khanam, S., \& Zuhra, F.-T. (2021). An Analysis of New VAT Law in Bangladesh: Changes \& Challenges. Beijing Law Review, 12, 875-887. https://doi.org/10.4236/blr.2021.123044

Received: August 11, 2021

Accepted: September 7, 2021

Published: September 10, 2021

Copyright $\odot 2021$ by author(s) and Scientific Research Publishing Inc. This work is licensed under the Creative Commons Attribution International License (CC BY 4.0).

http://creativecommons.org/licenses/by/4.0/

(c) (i) Open Access

\begin{abstract}
With the adoption of the Sustainable Development Goals (SDGs), taxation has once again taken up a central spot on the international development agenda. Value Added Tax (VAT) makes up most of the revenue from taxes in Bangladesh who was one of the first two South Asian countries to adopt VAT. Although the introduction of VAT in Bangladesh has proved to be comparatively successful in terms of increasing tax revenues, the effectiveness of the tax has been seriously eroded due to a number of deviations from the standard principles of VAT which have crept into the tax system in the last three spans. Hence the new "The VAT and Supplementary Duty Act, 2012" emerges with vast hope and prospect and also with challenges of implementation. This study aims to review the basic structure of VAT system under the new law and the major changes thereon through a qualitative approach based on document analysis. Findings reveal the nonconformity with the objectives of the law and suggest the deviations back on track with a boost in tax administration and a political influence free environment in Bangladesh context.
\end{abstract}

\section{Keywords}

Vat, Revenue, Vat Registration, Tax Rates, Tax Administration

\section{Introduction}

Bangladesh, a relatively young country in the South Asian subcontinent, emerged with high expectations of establishing an effective system of government by resolving the problems that had been hindering its development. Strengthening the internal revenue collection and mobilization of internal resources is a crucial component in mitigating the problem. Here, tax reform is the process of changing the way taxes are collected or managed by the government 
with different goals. Some seek to reduce the level of taxation of all people by the government. Some seek to make the tax system more progressive or less progressive. Others seek to simplify the tax system and make the system more understandable or more accountable. Bangladesh adopted value added tax (VAT) in 1991, replacing its age-old excise duty on domestically produced goods and services and sales tax at the importation stage, with the express aims of expanding the tax base, simplifying the tax collection procedure, and curbing tax evasion (Saleheen, 2013). Bangladesh signed the World Trade Organization (WTO) agreement, and this entails scaling down and/or abolition of duties and taxes on a wide range of items. Moreover, developing countries faced the decline of financial flows from international public and private sources by $12 \%$ between 2013 and 2016 (OECD, 2018). Understanding the facts, Bangladesh is now seriously trying to reform her taxation policies and enacted the new VAT and Supplementary Duty Act, 2012 with the effect from July 01, 2019 (NBR Bangladesh homepage URL, n.d.). Although the base of the VAT system has been expanded, however, because of political expediency numerous distortions have crept in overtime and the VAT system started to underperform considerably, given its potential.

The general objective of the study is to examine the various issues relating to VAT and identify the major changes made to the VAT Act 2012. It also aims to explore the consequences of the changes for the operations of VAT administration, consider the effects of the changes in terms of principles and implementation.

\section{Method}

As Creswell (2009: 18) observes, when a phenomenon is poorly understood or under-researched, qualitative methods are a useful tool as they can explore potential avenues for further research, qualitative approaches are therefore selected in this case and the study has been conducted on the basis of previous and new VAT laws, rules and regulations. Besides, data and information have also been collected from the secondary sources gathered from journal articles, books, reports, policy papers, national daily newspapers etc. Following studies within the constructivist framework that favor qualitative methods in which focus is on actors' perception of reality (Denzin and Lincoln, 2005: 3), this study applied the document analysis approach, within an interpretive framework. Here the authors employed with the data by way of reading in a systematic approach, taking notes, and marking pertinent paragraphs and sentences. A detailed search was undertaken on VAT laws and the related academic literature and policy reports. The data of all sources are transformed into analyzable texts which are edited, presented and used to draw conclusions (Miles \& Huberman, 1994).

\section{Theoretical Framework of the Study}

This study includes a review of basic characteristics of VAT, Working of VAT System, Indicators of VAT Compliance, Determinants of Taxpayer Behaviour, 
and Introduction of new VAT Law and VAT Management System in Bangladesh.

\subsection{Basic Characteristics of Value Added Tax}

VAT is a percentage-wise tax on the value added to a commodity or service as each constituent stage of its production and distribution is completed. There are three types of value-added tax used around the world; each is different in the ways that taxes on investment (capital) expenditures are handled. The most common is the consumption method, which allows businesses to immediately deduct the full value of taxes paid on capital purchases. The second is the net income method, which allows gradual deduction of VAT paid on capital purchases over a number of years, much like depreciation. The third type, gross national product method of value-added tax, provides no allowance for taxes paid on capital purchases. The name of this type of tax is derived from the fact that the tax base is approximately equal to private GNP. The consumption method is most favored among general populations because it most equally taxes income from labor and capital and promotes capital formation. VAT is to be paid as withholding tax and VAT is collected, deducted and deposited by the receiver of the services or the persons paying the price or commission as the case may be. For any other goods and class of goods or services, VAT is to be paid at the time as indicated in the National Board of Revenue (NBR) rule in Bangladesh.

There are two main methods of calculating VAT: the credit-invoice or invoice-based method, and the subtraction or accounts-based method. Using the credit-invoice method, sales transactions are taxed, with the customer informed of the VAT on the transaction, and businesses may receive a credit for VAT paid on input materials and services. The credit-invoice method is the most widely employed method, used by all national VATs except for Japan. Using the subtraction method, at the end of a reporting period, a business calculates the value of all taxable sales then subtracts the sum of all taxable purchases and the VAT rate is applied to the difference. The subtraction method VAT is currently only used by Japan, although subtraction method VATs, often using the name "flat tax", have been part of many recent tax reform proposals by US politicians (Bickley, 2006).

In theory, value-added tax systems with a uniform rate are neutral to all forms of productive input. However, countries across the world have had to modify the VAT system with multiple rates and exemptions to meet political, economic, and social needs.

Most nations do not assess any tax on necessities such as food, medicine, and shelter. And because of the difficulty in computing value added tax, the professional services such as banking, accounting, and insurance are often exempt. The largest variation from uniform tax rates is the zero tax rates on exports. Since taxes will likely be assessed at a product's destination, many do not impose a tax on the final selling price of exports. To compensate, the VAT is applied to im- 
ported products.

\subsection{Working of VAT System}

VAT is imposed on the value of the output of a firm less than the value of goods and services purchased from other firms. As its name suggests, VAT is paid on the value added at each production stage: firms pay VAT on the difference between total sales and total input costs. According to the self-enforcement hypothesis in the VAT system, firms have an incentive to ask their suppliers for accurate receipts because they can deduct input costs from their VAT bill. This incentive builds the creation of paper trails directly into the tax structure. But the built-in incentive structure breaks down at the final stage (Consumer Stage). While it is in the interest of firms to ask suppliers for receipts in order to deduct input costs from their VAT bill, consumers have no incentive to do so. Since the amounts are recorded in two sets of books-purchase register and sale register, the risk of cross-checks is thought to deter firms from reporting differing amounts (Bird and Gendron, 2007).

\section{Indicators of VAT Compliance:}

Tax compliance refers to the extent to which a taxpayer meets the following four obligations (Alink and Kommer, 2011):

- Registration in the system;

- Timely filing of tax returns;

- Reporting of complete and accurate information; and

- Payment of taxation obligations on time.

Some indicators that are used to monitor VAT compliance level are presented in Table 1.

\subsection{Determinants of Taxpayer Behavior}

Research efforts on taxpayer behavior have identified a large number of possible determinants of compliance and non-compliance. Pioneers Allingham and Sandmo (1972) simply stated that non-compliance was a product of the risk of detection and punishment in the form of tax penalties and other sanctions. Their model was based on pure rational economic risk calculation. Although there

Table 1. Some indicators of VAT compliance.

\begin{tabular}{cl}
\hline Type of Risk & Indicators of VAT Compliance \\
\hline Registration & $\begin{array}{l}\text { - } \begin{array}{l}\text { Trend in the percentage of registered taxpayers (by specified } \\
\text { entity type) compared to estimates of potential VAT payers }\end{array} \\
\text { Filing }\end{array}$ \\
- & Trend in the percentage of returns filed on time by entity type \\
Correct Reporting & $\begin{array}{l}\text { - Net VAT revenue tracked against changes in consumer } \\
\text { expenditures and levels of imports }\end{array}$ \\
& $\begin{array}{l}\text { Net VAT collection/estimates of VAT base (derived from } \\
\text { national accounts data) }\end{array}$ \\
Payment & - Trend in the percentage of tax paid on time by entity type
\end{tabular}


might be some value in their approach, it does not explain why most taxpayers comply even in situations when there is hardly a chance of detection. Methods to improve compliance mainly based on examination and sanctions are clearly not effective (Kirchler, 1998); (Tyler, 1990) and can even turn out to be counterproductive (Blumenthal et al., 1998). The use of threat and coercion by tax administration can easily lead to the opposite behavior. People react against the use of power, especially when it is unwarranted and illegitimate (Biner, 1988). Webley and others (2006) found a number of aspects influencing taxpayers' non-compliance, including: Opportunity is an important explaining factor; perception of equal and fair treatment; individual differences in personality of people; social norms (beliefs about others' behaviours); and knowledge of the tax system and the requirements involved.

\subsection{Introduction of New VAT Law \& VAT Management System in Bangladesh}

Introduced in France for the first time, Value Added Tax (VAT) was introduced in Bangladesh in place of Sales Tax in 1991. The purposes of the introduction of the new VAT were to replace the old age sales tax, mobilize more internal revenue, to introduce a single flat rate covering a wide range of goods and services production, and ensure equity by bringing transparency and accountability in the taxation system of Bangladesh (Lalarukh and Salahuddin, 2013). VAT introduced in Bangladesh in its initial form was a sort of consumption tax (by allowing the purchase of capital goods as input), which extended its coverage up to the level of import, production or manufacture, and service rendering but not to export (which is zero-rated), wholesale or retail level. However, because of some inherent defects in its application, the old VAT Act has been replaced by The VAT and Supplementary Duty Act, 2012 which came into effect from 1 July 2019. The National Board of Revenue (NBR) is the central authority for tax administration in Bangladesh. It was established by President's Order No. 76 of 1972. Administratively, it is under the Internal Resources Division (IRD) of the Ministry of Finance (MOF). MOF has 3 Divisions, headed by 3 permanent Secretaries to the Government, namely, the Finance Division the Internal Resources Division (IRD) and the Economic Relations Division (ERD). The Secretary of IRD acts as the Chairman of NBR.

In the Preamble of the new VAT law, four objectives have been articulated; namely, expansion of tax-base, simplification of VAT collection procedure, integration of procedure and making other relevant provisions. Simplification has been an important objective of the new VAT law which appears elusive in the current central registration regime. VAT management system in Bangladesh has a number of steps:

1) Registration for VAT;

2) Declaration of value of manufactured commodities;

3) Assessment of duty and taxes;

4) Payment of duties and taxes; 
5) Delivery of goods and services; and

6) Submission of return along with VAT payment.

In VAT management, first it requires making a list of the sellers which is called registration. Then, the sellers require keeping records of sale, purchase, VAT payment etc., so that the regulatory authority can check from time to time the appropriateness of payment of VAT. The sellers are of different types; such as: individuals, proprietorship firms, partnership firms, limited companies, trusts, societies, non-government organisations (NGOs), government enterprises etc., with one, several or dozens of points of manufacturing, warehousing, sale, trading, service rendering and management offices. So, there arose the concept of unit registration and central registration. Registering one unit at one place is called unit registration and registering multiple units together is called central registration. Account is considered to be the most relevant and common basis. Every entity has an account. An entity with one or multiple units maintains an account incorporating all transactions. Most documents of an entity require to be maintained under company law and VAT law. These documents are the evidences of purchase and sale, income and expenditure, profit and loss. So, one entity/company, one Business Identification Number (BIN) was adopted as the basic principle of registration.

\section{Findings \& Discussions}

Following findings are based on The VAT and Supplementary Duty Act, 2012 and the changes made by the Finance Act, 2019 and the VAT rules thereon which are given effect for the implementation of the new VAT laws in Bangladesh.

\subsection{Value Added Tax Laws in Bangladesh}

Rules and regulation enacted in the following laws are taken into consideration to impose Value added Tax on goods and services:

1) The VAT and Supplementary Duty Act, 2012: The VAT and Supplementary Duty Act, 2012 has 139 sections, numerous subsections, and three schedules containing the necessary provisions for the purpose of imposing Value Added Tax.

2) Value Added Tax Rules: The National Board of Revenue prepared the relevant rules followed in the administration of the VAT Act.

3) Finance Act. To give effect to the various proposals in the annual budget covering the areas of direct and indirect taxes, Finance Act is issued. It contains various applicable tax rates and amendments to the Value Added Tax Act \& Rules.

4) SRO (Statutory Regulatory Orders): According to the Value Added Tax Act, NBR can issue certain circular as and when necessary. The provisions of these SROs are also to be considered as the time of imposing VAT.

5) VAT Case Law: In the course of assessment proceeding, the judgement 
given by the courts regarding the interpretations of any provisions of the VAT Act may also act as guidance to the assessing officers and the assesse in similar relevant circumstances.

\subsection{Key Changes to the VAT Law}

The Value Added Tax and Supplementary Duty Act 2012 was enacted in December 2012 after three years of preparations for completing the draft with inputs from international and national experts and extensive consultations with the business community. At the time of enactment of the law, it was understood that effective implementation of the new law will require three years of preparations in terms of automation of the VAT administration and restructuring of the VAT administration along functional line. In the event, due to delays in automation and resistance from the business community, a new VAT Law has been introduced after seven years. However, the new VAT law is a compromise outcome entailing fundamental and sometimes arbitrary changes to the original VAT Act 2012 as part of government's understanding or political compromise with the business community represented by the Federation of Bangladesh Chamber of Commerce and Industries (FBCCI). The new VAT law was made fully effective from July 1, 2019 bringing changes through Finance Act, 2019.

First, the most important change is with respect to introduction of multiple VAT rates. Under the amendments in 2019 to the new VAT Act 2012, the government moves away from a uniform 15 percent VAT rate envisaged in the VAT and Supplementary Duty Act 2012 and instead introduced many VAT rates: 15 percent at the import stage; 10 percent at domestic manufacturing stage; 7.5 percent at wholesale stage; 5.0 percent at retail stage; and several other truncated rates stated in Schedule 3-on selected products primarily to limit price pressures arising from the changes made under the new system. One saving grace is that, domestic manufacturer, wholesalers and retailers may still opt for the original 15 percent VAT rate with full input tax credit, if they consider that advantageous from their business point of view. Many countries have multiple VAT rates but that generally ranges between 3 - 5 rates and are applied at different rates on different products and services taking into account socio-economic and health-related issues. But Mansur (2019) simply states that Bangladesh is now an individual country in the world where different VAT rates will be applied to same products at different stages of processing or sales.

Secondly, the second most important change is elimination of input tax credit. Domestic manufacturers and other suppliers will not be able to take input tax credit who are paying VAT at rates different from the 15 percent rate. The decision to eliminate the input tax credit provision for supplies at rates different from 15 percent is understandable because if input tax credit is allowed, in many instances there will be refund of taxes to the manufacturers and other suppliers entailing substantial revenue loss for the government. The input tax credit will generally exceed the VAT on the output at every stage of production and sales as 
long as downstream VAT rates are lower than 15 percent. A fully operational input credit system is not possible under the multi-rate and multi-stage VAT rates system as designed and implemented in Bangladesh.

Thirdly, reliance on advance collection of VAT at the import stage has further increased under the new VAT law.

Fourthly, a manufacturer manufacturing at one place and selling through multiple places shall not be entitled with central registration. If entities selling goods or services are not identical or similar they cannot pay VAT centrally with ease.

The original 2012 VAT Act intended to reduce dependence on supplementary duty and also lower the level of domestic protection by reducing the long list of items subject to supplementary duty (SD) and applying the SD rates equally on both domestic and imported goods and services. In the event, the new VAT law maintained the discriminatory nature of SD by applying it primarily on imports. As a result, instead of reducing the degree of protection offered through SDs, the level of protection further increased.

Besides, The National Board of Revenue continues to make changes in the law to fine tune it and fulfill the demands of the business community as the VAT wing of the NBR issued so many statutory regulatory orders, special orders, general orders, and directives amending the provisions of the law.

\subsection{Key Changes to the Vat Administration}

In order to put in place an automated VAT system, the National Board of Revenue (NBR) initiated a comprehensively designed VAT online project with financial and technical support from the World Bank. The VAT online project aimed at ease of doing business through fully automated registration system, fully automated on-line VAT return submission, and fully automated VAT payments through VAT registered person's bank account. VAT and Turnover Tax taxpayers have to be re-registered and issued a new business identification number. Many monotonous features in the present law have been abolished by removing the requirements for taxpayers to receive price approvals from tax officers, deposit VAT in the government treasury, and attach to the VAT return copies of individual VAT invoices and payment confirmations. Electronic Cash Registrar (ECR) and Point of Sales (POS) machines for shops, hotels, resorts and other trading units in district towns have been made mandatory in order to ensure deposit of VAT collected from consumers to the Government treasury. Taxpayers will receive a much higher level of service and assistance, including access to a centralized Contact Center, a small business advisory visitation program, and a variety of electronic services.

\subsection{Effect of the Changes}

In most respect the new VAT Law deviates fundamentally from the VAT Act of 2012 and is very similar to the VAT Act of 1991. First, the number of items sub- 
ject to rates other than 15 percent under the new law are listed in Schedule 3 of the VAT Act by amendment. The list is very similar to the list of products subject to truncated base or tariff value based system under the VAT Act of 1991. Second, similar to the 1991 law, the new VAT law does not allow input tax credit for those firms which are producing/supplying items listed in Schedule 3 of the new VAT Act. In many cases, the new law has become worse than the old law (Uddin, 2020).

Multiple rates will make the tax system much more complicated and hence difficult to administer and create more room for tax evasion and shifting by tax-payers, which will eventually result in loss of revenue (Mansur, 2019).

The multiple VAT rates will also create problem with transparency in accounts. Most VAT registered persons who are engaged in wholesale and retail trade would opt for lower VAT rates and waive input tax credit in order to avoid transparent books of accounts.

Under the new VAT system, if Bangladeshi manufacturers sub-contract components of the production process to other firms such sub-contracting will be considered a new manufacturing activity/process causing additional 10 percent tax on the subcontracted component which cannot be adjusted by the parent firm against its output tax. In the process, horizontal structure of production-with large factories and companies sub-contracting part of the production processes to smaller ones-will become non-viable and production process will become increasingly vertical going against the global norm (Mansur, 2019).

The changed law appears to be not in conformity with the objective and spirit of standard central VAT registration. Most of the manufacturers here, are manufacturing at one place and selling through multiple places. At present, if a manufacturer is a limited company having one head office with a separate manufacturing place and 10 sale-centres, it needs 12 VAT registrations. Thus it unreasonably limits the scope of central registration (Rouf, 2021).

Now there is no way that commercial importers would be able to adjust the advance VAT by selling the products in the domestic market, and accordingly they will simply increase prices by this amount and pass on this tax to buyers and create cascading of taxes. Even for most manufacturers it will be difficult to adjust this advance tax against their output tax.

Progress with VAT automation process has gone through periods of ups and downs. Although the VAT Law 2012 envisaged a completely automated taxpayer-friendly system of tax administration and registration and payment systems in reality NBR is very far from that. This automated system is not ready as yet and only VAT registration process has been automated and online return submission process has been tested with large taxpayers.

The other key element of improving VAT revenue collection was the introduction of Electronic Fiscal Devises (EFD) at every VAT outlet and its effective monitoring with a view to increase compliance with the new VAT system. The idea is good, but if we review the past performance of NBR with Electronic Cash 
Register (ECR) system we should be doubtful about the EFD introduction as well. ECRs were supposed to be introduced at least 10 - 15 years ago. It was mandated by law for many types of VAT-registered enterprises, but there was no follow-up and no compliance (Mansur, 2019).

\subsection{Discretionary Powers in Bangladesh VAT Regime}

Committed to the principle of the rule of law as well as to equality before the law, Bangladesh operates under the doctrine of the separation of powers with separate legislative, executive, and judicial powers vested respectively in the Parliament, the Executive Government, and the Judiciary. The Parliament has the fundamental power to impose tax as, according to Article 83 of the Bangladesh Constitution, "No tax shall be levied or collected except by or under the authority of an Act of Parliament". Within the framework of the provisions of the constitution, it is through the express legislation of Parliament that a great deal of authority has been delegated to the Executive Government, including the tax authority. Discretionary powers have been granted by the Act to the following three sets of actors:

1) The Government represented by the Internal Resources Division under the Ministry of Finance.

2) The NBR, the apex body for the formulation and implementation of tax policy.

3) VAT officials at different hierarchical levels.

The functions of these three sets of actors overlap with each other. While the VAT officers act as the agents of the Government and the NBR, the functions of the Government and the NBR differ only in the procedure of discharging their responsibilities. The first two actors are in fact two facades of the same body.

Regarding the nature of discretions, it can be said that the discretionary powers granted to the Government and the NBR are ultimate powers as they are not subject to review other than by their own volition. In the case of Bangladesh's VAT regime, the amount of secondary legislation in the form of SROs, rules, general orders, and notifications is innumerable.

Many taxpayers and VAT practitioners allege that to find a valid legal provision for a certain matter is tantamount to wandering in a maze comprised of a plethora of rules, orders and notifications-some still valid, some rescinded, some substituted by others (Saleheen, 2013).

Last but not the least, the use of discretionary powers in tax law has been found to prompt too much litigation. Litigation filed by aggrieved taxpayers has been identified as a serious bottleneck in the collection of tax revenue in Bangladesh.

\subsection{Political Limitations to Domestic Resource Mobilization}

Strong political commitment to tax reform is lacking in Bangladesh, and the disconnection between field-level tax officials and tax-evading businesses has further undermined tax reform efforts from both within and outside the NBR. 
The VAT Act of 2012 was drafted by the NBR with technical assistance from the IMF and IFC in an effort to improve the tax system-specifically the elasticity of the VAT and the efficiency of its administration. Once finalized, the new VAT was signed into law by Parliament in December 2012, with the aim to make it effective on July 1, 2015, a date set as one of the IMF's program conditions. As the IMF program lapsed and as the Bangladeshi government's financial position improved with the central bank's reserves exceeding eight to nine months of goods and services imports, the government lost interest in the IMF program. When the NBR was willing to implement the VAT at last and the finance minister was fully committed to it, as well, Bangladesh's government once again postponed the new VAT law by two years, to FY20. This move was because of strong resistance and political lobbying by the Federation of Bangladesh Chamber of Commerce and Industries (FBCCI) and was further influenced by the general elections of December 2018. Although the government was interested in getting more revenue through an improved VAT system, the election cycle and its associated political considerations ultimately postponed the effect of law and thus later on leads major deviation from the Act of 2012 under the protest from businesses, particularly from the FBCCI (Mansur, 2020).

The reform activities in Bangladesh illustrate an environmental dependency model where the changes occur in response to the political and economic environment in the context of which the tax policy makers operate. Hence tax reform in Bangladesh appears to be mainly the product of bureaucratic politics who seeks to protect their position by minimizing the political cost of tax program while preventing a budget shortfall.

\subsection{Encouraging Trends}

Over the years, a number of efforts were made to strengthen tax revenue mobilization and improve the country's tax structure (Mansur, 2020). In 1991, Bangladesh embarked on the major tax reform initiative by introducing the VAT system and simultaneously, significant reduction of import tariffs occurred. Prior to these reforms, trade-based taxes dominated the tax structure in Bangladesh, but after the introduction of the VAT in 1991, the share of VAT revenue increased substantially, growing to 29 percent in the decade 2004-2014 (Table 2). Revenue lost from trade-based taxes was compensated through the expansion of VAT coverage of many services, as well as to the wholesale and retail levels.

Table 2. Evolution of VAT revenue, 2000-2017.

\begin{tabular}{ccccc}
\hline \multicolumn{3}{c}{ In relation to GDP (\%) } & & \multicolumn{2}{c}{ In relation to total Revenue (\%) } \\
\hline & $\begin{array}{c}\text { 2000-2002 } \\
\text { Mean }\end{array}$ & $\begin{array}{c}\text { 2014-2017 } \\
\text { Mean }\end{array}$ & $\begin{array}{c}\text { 2000-2002 } \\
\text { Mean }\end{array}$ & $\begin{array}{c}\text { 2014-2017 } \\
\text { Mean }\end{array}$ \\
\hline Tax revenue & 7.47 & 9.99 & 79.30 & 85.88 \\
Value added tax (VAT) & 2.41 & 3.41 & 25.62 & 29.32 \\
\hline
\end{tabular}

Sources: Ministry of Finance and the National Board of Revenue (NBR). 
Furthermore, despite the predominance of discretionary powers in the decision-making process in the Bangladesh VAT regime, there are a couple of encouraging trends. First, the Bangladesh VAT law grants the taxpayers-existing or potential - the right to appeal against any decision of any VAT officer. The first step of the appeal process is limited to departmental ambit: appeal to the Commissioner (Appeal) in the case of a decision given by an officer below the rank of commissioner, and appeal to a VAT Tribunal in the case of an appeal against the decision of a commissioner. After exhausting the departmental appeal procedures, the aggrieved can go to a court of law. The second emerging trend is the introducing of Alternative Disputes resolution (ADR) provisions for dispute in income tax, VAT and customs which facilitates the taxpayers to settle their differences with the help and guidance of a facilitator.

\section{Conclusion}

In Bangladesh, VAT has been found to be moderately revenue boosting in the first years of introduction. In terms of complexity of development, demand for human resources and the impact it will have on the society, the implementation of VAT in Bangladesh will rank as one of the most significant development projects ever undertaken in this country. The introduction of VAT in any country poses a colossal management problem. The transitional issues need special attention which often spans several years. Once the transitional phase is over, and the base is consolidated, then the benefits of the system come into full play. It is, therefore, imperative to strive hard to lay the system firmly in place. However, the major changes that have been made to the already parliament-approved original VAT Act of 2012 just before its implementation in 2019 have fundamentally changed the character of the 2012 VAT Act by swapping away the basic principles of VAT, and we are not assured how much argumentative impact this new VAT law will have in time. Hence, reforms must be initiated in all three major areas of taxes, both in terms of tax policy and tax administration (Mansur, 2020), including sorting out tax policy functions from tax administration functions and shifting tax policy functions away from the NBR to a separate division under the Ministry of Finance and introducing the VAT Act of 2012 without making any fundamental changes; automating and reshuffling all tax-related business processes and transforming tax administration laterally functional lines. Finally, political commitment is essential to make reform programs a success.

\section{Conflicts of Interest}

The authors declare no conflicts of interest regarding the publication of this paper.

\section{References}

Alink, M., \& Van Kommer, V. (2011). Handbook on Tax Administration. IBFD.

Allingham, M. G., \& Sandmo, A. (1972). Income Tax Evasion: A Theoretical Analysis. Journal of Public Economics, 1, 323-338. https://doi.org/10.1016/0047-2727(72)90010-2 
Bickley, J. M. (2006). Value-Added Tax: A New U.S. Revenue Source (pp. 1, 3)? Congressional Research Service. RL33619.

Biner, P. M. (1988). Effects of Cover Appeal and Monetary Incentives on Survey Response: A Reactance Theory Application. Basic and Applied Social Psychology, 9, 99-106. https://doi.org/10.1207/s15324834basp0902_3

Bird, R., \& Gendron, P. P. (2007). The VAT in Developing and Transitional Countries. Cambridge University Press. https://doi.org/10.1017/CBO9780511619366

Blumenthal, M., Christian, C. W., \& Slemrod, J. B. (1998). The Determinants of Income Tax Compliance: Evidence from a Controlled Experiment in Minnesota. NBER Working Paper, w6575. https://doi.org/10.3386/w6575

Creswell, J. W. (2009). Research Design: Qualitative and Mixed Methods Approaches. Sage Publications.

Denzin, N. K., \& Lincoln, Y. S. (2005). The Sage Handbook of Qualitative Research (3rd ed.). Sage Publications Ltd.

Kirchler, E. (1998). Differential Representations of Taxes: Analysis of Free Associations and Judgments of Five Employment Groups. The Journal of Socio-Economics, 27, 117-131. https://doi.org/10.1016/S1053-5357(99)80080-8

Lalarukh, F., \& Salahuddin, C. M. (2013). Contribution of VAT to the GDP of Bangladesh: A Trend Study. Journal of Business, 34, 131-141.

Mansur, A. H. (September 16, 2019). The New Vat Act: A Compromise Outcome-II. The Financial Express.

https://thefinancialexpress.com.bd/views/the-new-vat-act-a-compromise-outcomeii-15 68646283

Mansur, A. H. (2020). Bangladesh: Impediments to Enhanced Revenue Mobilization and Equitable and Efficient Spending. CGD Policy Paper 167, Center for Global Development. https://www.cgdev.org/publication/bangladesh-impediments-enhanced-revenue-mobil ization-and-equitable-and-efficient

Miles, M. B., \& Huberman, A. M. (1994). Qualitative Data Analysis: An Expanded Sourcebook. Sage.

National Board of Revenue (NBR) Bangladesh (n.d.). https://nbr.gov.bd/regulations/acts/vat-acts/eng

OECD (2018). Revenue Statistics 2018 Tax Revenue Trends in the OECD. OECD Publishing.

Rouf, M. A. (2021). Central VAT Registration in Bangladesh: An Appraisal. The Financial Express.

https://thefinancialexpress.com.bd/views/views/central-vat-registration-in-bangladeshan-appraisal-1619621112

Saleheen, A. M. (2013). The Use of Discretions in Taxation: The case of VAT in Bangladesh. eJournal of Tax Research, 11, 97-113.

Tyler, T. (1990). Justice, Self-Interest, and the Legitimacy of Legal and Political Authority. In J. Mansbridge (Ed.), Beyond Self-Interest (pp. 171-179). University of Chicago Press.

Uddin, J. (2020). The New Vat Sees Little Success Due to Frequent Change. New Age. https://www.newagebd.net/article/95602/new-vat-law-sees-little-success-due-to-freque nt-changes

Webley, P., Adams, C., \& Elffers, H. (2006). Value Added Tax Compliance. In E. J. McCaffery, \& J. Slemrod (Eds.), Behavioral Public Finance: Toward a New Agenda (pp. 175-205). Russell Sage. 